\title{
Protocol for prevention of pressure ulcer
}

\author{
Protocolo para prevenção de úlcera por pressão
}

Alyne Gonçalves Stuque ${ }^{1}$, Vanessa Damiana Menis Sasaki ${ }^{1}$, André Aparecido da Silva Teles ${ }^{1}$, Mary Elizabeth de Santana $^{2}$, Soraia Assad Nasbine Rabeh ${ }^{1}$, Helena Megumi Sonobe ${ }^{1}$

Objective: to analyze the national and international scientific evidence to establish recommendations in the elaboration of a nursing protocol for the prevention of pressure ulcer. Methods: integrative review with search in the databases LILACS, MEDLINE and BDENF, using the descriptors "pressure ulcer", "protocol" and "secondary prevention", with final sample of 21 scientific articles. Results: the sample was categorized into two themes: "Protocols", which recommends sociodemographic and clinical specificities with adoption of instrument and scales to measure skin and pressure ulcer lesions, in addition to nursing interventions; and "Strategies for implementing the protocol", which emphasizes the leadership of nurses, management support, continuing education, prediction and provision of human and material resources as fundamental for the implementation. Conclusion: in the elaboration of a protocol for prevention of pressure ulcer, clinical and therapeutic aspects of the patients should be included, as well as material and human resources for its implementation.

Descriptors: Pressure Ulcer; Secondary Prevention; Guideline Adherence; Nursing.

Objetivo: analisar as evidências científicas nacionais e internacionais para estabelecer recomendações na elaboração de protocolo de enfermagem para prevenção de úlcera por pressão. Métodos: revisão integrativa com busca nas bases de dados LILACS, MEDLINE e BDENF, com descritores "úlcera por pressão", "protocolo" e "prevenção secundária", com amostra final de 21 artigos científicos. Resultados: amostra categorizada em dois temas: "Protocolos" que recomenda especificidades sociodemográficas e clínicas com adoção de instrumento e escalas para dimensionar as lesões de pele e úlcera por pressão, além de intervenções de enfermagem; e "Estratégias de implementação do protocolo" que valoriza liderança dos enfermeiros, apoio da gestão, educação permanente, previsão e provisão de recursos humanos e materiais como fundamentais para a implantação. Conclusão: na elaboração de protocolo de prevenção de úlcera por pressão recomenda-se incluir aspectos clínicos e terapêuticos dos pacientes, assim como recursos materiais e humanos para a sua implantação.

Descritores: Úlcera por Pressão; Prevenção Secundária; Fidelidade a Diretrizes; Enfermagem.

\footnotetext{
${ }^{1}$ Universidade de São Paulo, Escola de Enfermagem de Ribeirão Preto. Ribeirão Preto, SP, Brazil.

${ }^{2}$ Universidade Estadual do Pará, Universidade Federal do Pará. Belém, PA, Brazil. 


\section{Introduction}

Pressure ulcer is an injury to the skin and/or underlying tissue due to pressure and tensions. Its incidence in Brazil is between 19.1\% and 39.8\%. These injuries occur regardless of care settings, and international prevalence rates vary between $3.5 \%$ and $41.0 \%$ and incidence is between 10.2 and $26.7 \%^{(1-3)}$.

Regarding the resolution of pressure ulcers, about $50.0 \%$ present tissue impairment classified in category II and $95.0 \%$ in categories III and IV, which do not heal in less than eight weeks. Patients often require prolonged and intermittent hospitalization, which leads to increased costs, time of direct care from the health team and rates of hospital infection ${ }^{(1-3)}$.

Providing care to the skin and tissue integrity is an element of nurses' practice, which includes pressure ulcer prevention through actions that aim to prevent the patient from presenting the risk factors that trigger this type of injury(2). The nursing team takes care of the patient full time and therefore has the opportunity to identify these factors in order to take action early.

Prevention of pressure ulcer is among the priority areas of action of the Patient Safety Program, recommended by the World Health Organization, in search of quality of care and patient safety in care contexts $^{(4)}$.

Nursing care to the patient with risk of pressure ulcer is still based on the individual knowledge of the nurse, often resulting in random and discontinued interventions. The systematization of care, based on scientific knowledge, provides the nurse with fundamental data about the patient and the potential risks to develop pressure ulcer, in addition to increasing the reach of desirable results with nursing interventions and the improvement of the quality of care ${ }^{(5)}$.

Pressure ulcer prevention must be undertaken by nursing and the entire multidisciplinary team, extending to managers and administrators, with a view to comprehensiveness as a policy and a right, in which care is decisive and does not cause harm. On the other hand, prevention is a way of organizing practices when protocols are built with participation of health professionals and focused to meet the demands of patients, respecting individuality, including special groups, which are more susceptible to develop pressure ulcers due to chronic and other limiting conditions $^{(2-3,5)}$.

In view of the above, this study aimed to analyze national and international scientific evidence to establish recommendations in the elaboration of a nursing protocol for the prevention of pressure ulcers.

\section{Methods}

This is an integrative review, grounded on the Evidence-Based Practice, aimed to establish recommendations for the elaboration of pressure ulcer prevention protocols, as it is a method that allows the synthesis of scientific production with critical analysis on a particular topic, evaluating the best evidences for the application thereof in improving the clinical practice of nursing ${ }^{(6-7)}$.

For the development of this study, six recommended steps were used: selection of the research question; selection of primary studies; presentation of the characteristics of the primary studies; analysis of primary studies; interpretation of results; and writing or reporting the review ${ }^{(6)}$.

In this way, the search for scientific production was carried out after establishing the question: "what are the recommendations of national and international scientific literature for the elaboration of protocols for prevention of pressure ulcer?".

Search was made in the electronic databases LILACS (Latin American and Caribbean Literature in Health Sciences), MEDLINE (Medical Literature Analysis and Retrieval System Online) and BDENF (Nursing Database), using the descriptors "pressure ulcer", "protocol" and "secondary prevention", from January 2015 to July 2016.

The inclusion criteria were: articles in Brazilian Portuguese, English, Spanish and French languages, 
which addressed the theme of the study and made it possible to answer the question; without temporal cut until July 2016 and being available in full in the Central Library of the University of São Paulo, Ribeirão Preto Campus. With the initial search 108 (100.0\%) articles were found, and after reading the abstracts, 81 (75.0\%) were excluded because they had no relation to the theme, and 27 (25.0\%) were pre-selected. Of these $27(100.0 \%)$ articles, six (22.0\%) were not available in full in the Central Library of the University of São Paulo, Ribeirão Preto Campus and, therefore, 21 (78.0\%) scientific articles constituted the sample, of which 12 (57.0\%) were indexed in the electronic databases MEDLINE, 05 (24.0\%) in the LILACS database and $04(19.0 \%)$ in the BDENF database.

In the analysis of the scientific evidence, the classification in seven levels was used: Level I - systematic reviews or meta-analysis of randomized controlled clinical trials; Level II - well-controlled randomized controlled clinical trials; Level III - well-designed clinical trials without randomization; Level IV - well-designed cohort and case-control studies (non-experimental); Level V - systematic reviews of descriptive and qualitative studies; Level VI - evidence from a single descriptive or qualitative study; and Level VII - evidence from the opinion of authorities and/ or expert committee reports ${ }^{(8)}$.

\section{Results}

The sample of 21 scientific articles was analyzed and categorized in two themes, "Protocols", with 12 articles, and "Strategies for implementing the protocol", with nine articles.

In the topic "Protocols" (Figure 1) 12 (100.0\%) articles were analyzed ${ }^{(9-20)}$ and nine $(75.0 \%)$ described the place of study ${ }^{(9-15,19-20)}$. Of these, five $(55.6 \%)$ were developed in Intensive Care Unit $^{(9,13-14,19-20)}$, two $(22.2 \%)$ in hospitalization units ${ }^{(10,12)}$, and two $(22.2 \%)$ in both health care contexts ${ }^{(11,15)}$.

Of the 12 articles analyzed (Figure 1), eight (66.6\%) addressed sociodemographic aspects ${ }^{(9-14,19-20)}$, including age, sex and skin color; two (25.0\%) included the origin of the patient ${ }^{(9,19)}$; seven (87.5\%) addressed clinical data such as main diagnosis and length of hospital stay, medications in use, definition of the type of clinical or surgical hospitalization ${ }^{(9-12,14,19-20)}$; three studies (43.0\%) addressed the body mass index ${ }^{(9-10,19)}$; two $(29.0 \%)$ the underlying diseases ${ }^{(9,12)}$; and one $(14.0 \%)$ included associated diseases ${ }^{(9)}$, previous hospitalization in Intensive Care Unit ${ }^{(10)}$, smoking, bladder/bowel function, history of pressure ulcer, surgical history ${ }^{(12)}$, hemoglobin values ${ }^{(20)}$, Acute Physiology and Chronic Health Evaluation II, Simplified Acute Physiology Score $2^{(14)}$ and degree of dependency ${ }^{(12)}$.

Age above 60 years was identified in six (75.0\%) articles as an important variable for a protocol for pressure ulcer prevention ${ }^{(9-12,14,19)}$.

The demographic characterization related to sex in eight articles ${ }^{(9-14,19-20)}$ points out that in four (50.0\%) studies there was a predominance of females $^{(10,11,13,19)}$, in three $(37.5 \%)$, of males ${ }^{(9,12,14)}$, and one article $(12.5 \%)$ did not explain this information ${ }^{(20)}$. Regarding the main diagnosis of hospitalization, three $(50.0 \%)$ articles did not describe it ${ }^{(12-13,20)}$, and the others reported different diagnoses ${ }^{(9-10,12)}$. In a study ${ }^{(9)}$, the most frequent diagnoses were related to the digestive system, followed by the cardiovascular and respiratory systems. For another author ${ }^{(10)}$, the hematological (33.0\%) and neoplastic (22.2\%) diagnoses stood out. However, other authors ${ }^{(12)}$ reported that neurological diseases accounted for $36.1 \%$ of their sample. The underlying pathologies may constitute a triggering factor for pressure ulcer due to the reduction of sensory perception, mobility and activity, which increase the risk for the development of these lesions.

An association between prolonged hospitalization time and the occurrence of pressure ulcer was reported after observing that the average length of hospital stay for patients with pressure ulcer (30.2\%) was higher when compared to patients who did not develop this type of injury $(17.8 \%)^{(12)}$. The appearance of new pressure ulcers occurred, on average, on 
the seventh day of hospitalization, as well as there was an increase in prolonged hospitalizations ${ }^{(14)}$. This is confirmed in another study ${ }^{(9)}$, in which the average hospitalization time of patients with pressure ulcer was 11.8 days, and $40.0 \%$ of the lesions developed on the fourth day of hospitalization and $90.4 \%$ in the first 15 days of hospitalization, which brings the conclusion that prolonged hospitalization time is related to the development of these lesions.

Patient severity scales such as Acute Physiology and Chronic Health Evaluation II, and Simplified Acute Physiology Score 2 were used in a study ${ }^{(14)}$. Among the analyzed articles that used scales to assess the risk for pressure ulcer development, $88.0 \%$ chose the Braden scale $^{(9-13,19-20)}$ and $12,0 \%$ used the Norton scale ${ }^{(14)}$.

Six (6) articles described pressure ulcer protocols; four $(67.0 \%)$ of which were prevention protocols $s^{(9,12-13,20)}$ and two (33.0\%) were prevention and treatment protocols $\mathrm{s}^{(14,15)}$.
Some protocols were based on the evaluation of risk for pressure ulcer by using the Braden scale, and the obtained score defined the conduct, presented in a flowchart of actions ${ }^{(13,15)}$.

Authors reported that after the implementation of a prevention protocol, the incidence of pressure ulcer was $23.1 \%$, and in the study prior to its implementation, the incidence was $41.0 \%$, in the same institution ${ }^{(9)}$.

When identified, pressure ulcers were evaluated in seven $(58.3 \%)$ articles ${ }^{(9-12,14-15,20)}$. However, in six $(86.0 \%)$ the evaluations were systematic with lesion staging ${ }^{(9-12,14,20)}$; five $(83.0 \%)$ articles included the location $^{(9-12,14)}$; and two (33.0\%) reported number of lesions ${ }^{(9,14)}$. One article addressed all the previous elements, besides the treatment and the use of a healing scale according to the Grupo Nacional para el Estudio y Assesoramento en Úlceras por Pressión y Heridas Crôni$\operatorname{cas}^{(14)}$. The systematic evaluations followed a script of

\begin{tabular}{|c|c|c|c|c|c|}
\hline $\begin{array}{l}\text { Reference/ } \\
\text { year }\end{array}$ & Database & Research objective & Journal & $\begin{array}{l}\text { Type of } \\
\text { study }\end{array}$ & $\begin{array}{c}\text { Level of } \\
\text { Evidence }\end{array}$ \\
\hline$A^{9}(2012)$ & Lilacs & $\begin{array}{l}\text { To verify the incidence of pressure ulcers after implementation } \\
\text { of a prevention protocol }\end{array}$ & $\begin{array}{l}\text { Rev Latino-Am } \\
\text { Enfermagem }\end{array}$ & $\begin{array}{l}\text { Descriptive, } \\
\text { quantitative }\end{array}$ & VI \\
\hline $\mathrm{A}^{10}(2011)$ & Lilacs & $\begin{array}{l}\text { To characterize the profile of patients, risk factors and } \\
\text { prevalence of pressure ulcers }\end{array}$ & Nursing & $\begin{array}{l}\text { Descriptive, } \\
\text { quantitative }\end{array}$ & VI \\
\hline $\mathrm{A}^{11}(2011)$ & Medline & To analyze the epidemiology of pressure ulcers & J Healthcare Qual & $\begin{array}{c}\text { Descriptive, } \\
\text { qualitative }\end{array}$ & VI \\
\hline $\mathrm{A}^{12}(2010)$ & Bdenf & Identify the incidence of pressure ulcers and their risk factors & $\begin{array}{l}\text { Rev Enferm UFPE } \\
\text { on line }\end{array}$ & $\begin{array}{l}\text { Descriptive, } \\
\text { quantitative }\end{array}$ & VI \\
\hline $\mathrm{A}^{13}(2010)$ & Lilacs & To evaluate the applicability of the Braden scale & $\begin{array}{l}\text { Rev Bras Ter } \\
\text { Intensiva } \\
\end{array}$ & $\begin{array}{l}\text { Descriptive, } \\
\text { quantitative }\end{array}$ & VI \\
\hline$A^{14}(2007)$ & Lilacs & $\begin{array}{l}\text { To determine the incidence and prevalence rates of pressure } \\
\text { ulcers }\end{array}$ & $\begin{array}{l}\text { Rev Bras Ter } \\
\text { Intensiva }\end{array}$ & $\begin{array}{l}\text { Descriptive, } \\
\text { quantitative }\end{array}$ & VI \\
\hline$A^{15}(2007)$ & Lilacs & $\begin{array}{l}\text { To develop a protocol for the prevention and treatment of } \\
\text { pressure ulcers }\end{array}$ & $\begin{array}{l}\text { Rev Hosp Clín } \\
\text { Porto Alegre }\end{array}$ & $\begin{array}{l}\text { Experience } \\
\text { report }\end{array}$ & VI \\
\hline $\mathrm{A}^{16}(2007)$ & Medline & $\begin{array}{l}\text { To compare four pressure ulcer guidelines as for quality and } \\
\text { content }\end{array}$ & $\begin{array}{l}\text { Worldviews Evid } \\
\text { Based Nurs }\end{array}$ & $\begin{array}{l}\text { Descriptive, } \\
\text { quantitative }\end{array}$ & VI \\
\hline $\mathrm{A}^{17}(2006)$ & Medline & $\begin{array}{l}\text { To analyze protocols of pressure ulcers and to relate their } \\
\text { content with prevalence }\end{array}$ & J Eval Clin Pract & $\begin{array}{l}\text { Descriptive, } \\
\text { quantitative }\end{array}$ & VI \\
\hline$A^{18}(2006)$ & Medline & $\begin{array}{l}\text { To describe the Guideline National Institute for Health and } \\
\text { Clinical Excellence (NICE): prevention and treatment of } \\
\text { pressure ulcers }\end{array}$ & Br J Comm Nurs & $\begin{array}{l}\text { Descriptive, } \\
\text { quantitative }\end{array}$ & VI \\
\hline $\mathrm{A}^{19}(2006)$ & Medline & $\begin{array}{l}\text { To determine the prevalence and presence of pressure ulcers } \\
\text { of microbial agents }\end{array}$ & La Presse Méd & $\begin{array}{l}\text { Descriptive, } \\
\text { quantitative }\end{array}$ & VI \\
\hline$A^{20}(2003)$ & Bdenf & $\begin{array}{l}\text { To describe the elaboration of a protocol for prevention of } \\
\text { pressure ulcer }\end{array}$ & Nursing & $\begin{array}{l}\text { Experience } \\
\text { report }\end{array}$ & VI \\
\hline
\end{tabular}

Figure 1 - Articles categorized in the topic "Protocols" according to reference, year, database, research objective, journal, type of study and level of evidence 
registration and data collection. However, one of the articles did not describe the elements used for this evaluation ${ }^{(15)}$.

Regarding the location of pressure ulcers, researchers used the anatomical references as recommended by the scientific literature. However, in relation to incidence, there was difference between the studies. In a study ${ }^{(9)}$ there was prevalence of the calcaneal (42.1\%), sacral (36.8\%), gluteal (15.8\%) and trochanteric $(10.5 \%)$ regions. In another study ${ }^{(12)}$, the sacral $(50 \%)$ and trochanteric $(25.0 \%)$ regions predominated. Also, other authors ${ }^{(19)}$ refer the sacral (27.0\%), followed by calcaneal region (13.0\%), ankle (12.0\%) and ischium (10.0\%) as prevalent.

Variations were also observed in relation to the staging of pressure ulcers. Authors reported that $68.4 \%$ of them were stage $\mathrm{II}^{(9)}$, whereas in another finding ${ }^{(12)}$ stage III was the most prevalent $(37.0 \%)$, followed by stage I $(27.7 \%)$.

Of the six articles that addressed the staging of the lesions, four used recommendations from the National Pressure Ulcer Advisory Panel ${ }^{(9-11,20)}$, one used the recommendations from the National Pressure Ulcer Advisory Panel and from the Grupo Nacional para el Estúdio y Assesoramento en Úlceras por Pressión y Heridas Crónicas ${ }^{(14)}$ and one did not specify it ${ }^{(15)}$.

Four guidelines on pressure ulcers were evaluated using the Appraisal of Guidelines Research and Evaluation tool, which evaluates methodological rigor and transparency on the development of a clinical guideline ${ }^{(16)}$. An analysis of pressure ulcer protocols in hospitals and long-term institutions verified the relationship between protocol implementation, content and prevalence of pressure ulcers, reinforcing the importance of evaluation with methodological rigor and transparency on the clinical guideline analyzed ${ }^{(17)}$.

On the other hand, the recommendations on prevention, treatment and implantation of pressure ulcer protocols have been presented in the National Institute for Health and Chronic Excellence (NICE) and distributed to health professionals working in hospitals with the aim of disseminating good practices in the management of these lesions ${ }^{(18)}$.

The topic "Strategies for implementing the protocol" (Figure 2) included nine (100.0\%) articles $^{(21-29)}$. Of these, six (66.6\%) addressed strategies for the implementation of protocols for prevention and treatment of pressure ulcer ${ }^{(21-22,25-27,29)}$, two (22.0\%) evaluated the knowledge of nurses about the risk scales and prevention behaviors ${ }^{(23-24)}$, and one (11.0\%) evaluated the conformity of care provided to pressure ulcers using quality indicators ${ }^{(28)}$.

Permanent education on pressure ulcer as strategy for implementing the protocol was addressed in six (66.6\%) articles, of which three (50.0\%) included the participation of the multidisciplinary team in courses and lectures ${ }^{(22,25,29)}$, and in the other three $(50.0 \%)$ articles different publics were approached as: nursing team ${ }^{(21)}$; specifically nurses ${ }^{(27)}$, and nurses and family members and/or caregivers ${ }^{(26)}$.

The topics covered included the prevention of pressure ulcer in six (66.6\%) $\operatorname{articles}^{(21-22,25-27,29)}$; the conceptual definition, treatment and risk assessment in four studies $(44.4 \%)^{(21,25-27)}$, and staging in three $(33.3 \%)$ articles ${ }^{(21,22,26)}$. Pressure ulcer prevention can be impaired by knowledge deficits of health teams ${ }^{(23,24)}$.

As strategic resources for implementing and maintaining protocols, articles ${ }^{(21,22,25-27,29)}$ described different alternatives adopted by institutions, according to available resources. Compulsory participation in the permanent education activity was reported as part of the implementation of a pressure ulcer prevention protocol, as well as training new employees at the time of admission. In addition, the training of multipliers in the nursing team was emphasized in order to ensure this implementation, which can be achieved by hiring a skin care consultant and more nurses, and by adopting the adherence to protocol as one of the criteria for assessing the performance of professionals ${ }^{(29)}$. 


\begin{tabular}{|c|c|c|c|c|c|}
\hline $\begin{array}{l}\text { Reference/ } \\
\text { year }\end{array}$ & Database & Research objective & Journal & $\begin{array}{l}\text { Type of } \\
\text { study }\end{array}$ & $\begin{array}{l}\text { Level of } \\
\text { Evidence }\end{array}$ \\
\hline$A^{21}(2012)$ & Medline & $\begin{array}{l}\text { To promote team's adherence and to decrease incidence of } \\
\text { pressure ulcers }\end{array}$ & Rehabil Nurs & $\begin{array}{l}\text { Experience } \\
\text { report }\end{array}$ & VII \\
\hline$A^{22}(2011)$ & Medline & $\begin{array}{l}\text { To quantify the prevalence of pressure ulcers and to assess } \\
\text { conformities }\end{array}$ & Int Wound J & $\begin{array}{l}\text { Descriptive, } \\
\text { quantitative }\end{array}$ & VI \\
\hline$A^{23}(2011)$ & Medline & To analyze recording and treatment of pressure ulcers & $\begin{array}{l}\text { Jt Comm J Qual } \\
\text { Patient Saf }\end{array}$ & $\begin{array}{l}\text { Descriptive, } \\
\text { quantitative }\end{array}$ & VI \\
\hline$A^{24}(2010)$ & Bdenf & $\begin{array}{l}\text { To investigate the performance of skin care among dependent } \\
\text { patients }\end{array}$ & $\begin{array}{l}\text { Rev Enferm } \\
\text { UFPE on line }\end{array}$ & $\begin{array}{l}\text { Descriptive, } \\
\text { quantitative }\end{array}$ & VI \\
\hline$A^{25}(2010)$ & Bdenf & To identify nurses' perception on pressure ulcer prevention & $\begin{array}{l}\text { Rev Enferm } \\
\text { UFPE on line }\end{array}$ & $\begin{array}{l}\text { Descriptive, } \\
\text { qualitative }\end{array}$ & VI \\
\hline$A^{26}(2006)$ & Medline & To determine the effects of a new pressure ulcer care policy & $\begin{array}{l}\text { Int J Qual } \\
\text { Health Care }\end{array}$ & $\begin{array}{l}\text { Descriptive, } \\
\text { quantitative }\end{array}$ & VI \\
\hline$A^{27}(2005)$ & Medline & To evaluate the computerization of guidelines for clinical practice & J Adv Nurs & $\begin{array}{l}\text { Descriptive, } \\
\text { quantitative }\end{array}$ & VI \\
\hline$A^{28}(2001)$ & Medline & $\begin{array}{l}\text { To evaluate the profile and care processes for patients at risk of } \\
\text { pressure ulcer }\end{array}$ & JAMA & $\begin{array}{l}\text { Descriptive, } \\
\text { quantitative }\end{array}$ & VI \\
\hline$A^{29}(2001)$ & Medline & $\begin{array}{l}\text { To determine the cost-effectiveness of a protocol for the } \\
\text { prevention of pressure ulcers }\end{array}$ & $\begin{array}{l}\text { Adv Skin } \\
\text { Wound Care }\end{array}$ & $\begin{array}{l}\text { Descriptive, } \\
\text { quantitative }\end{array}$ & VI \\
\hline
\end{tabular}

Figure 2 - Articles categorized in the topic "Strategies for implementing the protocol", according to reference, year, database, research objective, journal, type of study and level of evidence

Authors of a study ${ }^{(21)}$ recommend the implementation of Skin Rounds, whose skin evaluations are carried out by multiplying nurses twice a week in all admitted patients. This would stimulate daily evaluation by the nurses in the services, as they claimed difficulty in prioritizing skin evaluation due to work overload. In addition, the dissemination of positive results would be a strategy for the recognition of the team's contribution.

Another recommended strategy is to create a team chosen by members according to clinical knowledge and leadership ability as a way of allying administrative management for implementing the protocol $^{(22)}$.

Identification with bedside posters for patients at risk of developing pressure ulcer and pocket cards with staging information and recording instructions for the team were used as a strategy to raise awareness and disseminate the protocol. A manual has been created for its implementation with wound coverage and care, accessible via intranet and posters in the hospital, as well as recording of injuries for the multidisciplinary team ${ }^{(25)}$.

Replacement of traditional hospital mattresses by mattresses with pressure reduction is considered as fundamental in the implantation of the proto$\mathrm{col}^{(21-22,25-26)}$. Prevention of pressure ulcers is rarely seen as a priority in health care institutions, and lack of leadership may be a barrier to the implementation of recommendations. However, a strong leadership in nursing can favor better prevention and treatment of these injuries ${ }^{(26)}$.

One of the greatest challenges for implementing protocols is the search for the quality of the recommendations, of the care practices of the professionals, of the local characteristics, of the incentives and of the factors inherent to the patient, based on scientific knowledge. The mere existence of clinical practice guidelines does not mean better results. Successful implementation must include effective continuing education, availability for changes in clinical practice, prediction and provision of human resources, equip- 
ment and supplies. And this must be assumed as part of the administrative policy in the health institution ${ }^{(27)}$.

\section{Discussion}

Conceptually, a protocol is a "document prepared in a systematic way for the assistance and guidance of health professionals on appropriate decisions in the care of patients under specific conditions". Six elements are fundamental in its elaboration: Situational diagnosis; Characterization of the clients; Definition of therapeutic options; Construction of service standards; Creation of instruments for systematization of treatment; and Implementation of the protocol ${ }^{(30)}$.

In the topic "Protocols", information such as sociodemographic and clinical profile, use of instrument for data collection, as well as use of scales to dimensioning skin lesions and pressure ulcers supported the conduction for the definition of nursing care that should be included in its elaboration.

Considering the high incidence rate and prevalence of pressure ulcer in Intensive Care Units, the identification of the profile of patients exposed to multiple factors, which potentiate the development of these lesions due to prolonged bed confinement, sedation, use of mechanical ventilation, motor and sensory dysfunction and use of vasoactive drugs, is fundamental in the elaboration of the protocol ${ }^{(9,12,14,19)}$.

In health institutions, most of the services are related to the elderly, who are susceptible to the development of pressure ulcers due to the aging process. This process results in alterations such as loss of elasticity, reduction of skin texture, muscle mass and frequency of cell replacement, which potentiate external factors such as pressure, friction and shear ${ }^{(9-10,12-13)}$.

Although the gender variable was not statistically significant for the risk of developing pressure ulcer ${ }^{(12)}$, in an Intensive Care Unit there was a prevalence of $57.1 \%$ in women due to their greater longevity and the occurrence of chronic diseases ${ }^{(13)}$.

In a French study, the prevalence of 5.3\% was identified in clinical and surgical units; however, in the
Intensive Care Unit, the prevalence was $20.6 \%^{(19)}$. In a Brazilian study in an Intensive Care Unit of a general hospital, the incidence was $41.0 \%$, which motivated the elaboration of a protocol for its prevention ${ }^{(9)}$.

In the analysis of the medical diagnoses that resulted in hospitalization of patients, the etiology showed to be of many causes, and the risk factors described helped in the evaluation for development of pressure ulcer. Therefore, in the clinical evaluation, considering individual risk factors, clinical evolution, physiological and psychosocial reactions and time of hospitalization is crucial ${ }^{(9-10,12)}$.

The use of instruments for assessing organic dysfunction of critical patients (Acute Physiology and Chronic Health Evaluation II, as well as the Simplified Acute Physiology Score 2) help in the prognosis of risk for death by refining the clinical evaluation of patients susceptible to developing skin lesions ${ }^{(14)}$.

In the topic "Strategies for implementing the protocol", key aspects were evidenced for the implementation of protocols, such as nurses' leadership capacity, support from managers, strategies for permanent education and for the implementation of protocols, as well as the provision of human and material resources, which should be included in the proposal of a protocol for prevention of pressure ulcer.

Braden scale in the evaluation of risk for pressure ulcer has presented high specificity and high sensitivity in comparison to other scales of risk prediction, which makes this evaluation more reliable and relevant, since it measures aspects such as sensory perception; humidity; mobility; nutrition; friction and shear $^{(5-6)}$. Another scale used for risk assessment is the Norton Scale, which has five parameters: physical condition; level of consciousness; activity; mobility and incontinence ${ }^{(6)}$.

According to some authors, investment for preventive measures is significantly lower in relation to treatment, besides generating quality of life and reducing hospitalization time. In this way, the identification of the client at risk for developing pressure ulcer, the Braden scale, a demonstration chart of suscepti- 
ble areas, the recording of skin changes according to pressure ulcer stages, and prevention and treatment guidelines are crucial for the development of proto$\operatorname{cols}^{(10,12-13,15,18-20)}$.

The implementation of preventive protocols should include elements such as: objective, proposal, definition of pressure ulcer, nursing interventions and preventive interventions. Implementation can be favored by raising awareness and training of the entire nursing team, acquisition of materials and equipment necessary for making it feasible and the adoption of pressure ulcer incidence as one of the quality indicators in the institution ${ }^{(9)}$.

Authors ${ }^{(11)}$ have studied the prevalence and incidence of these lesions for 15 years and concluded that they did not increase significantly due to prevention and treatment strategies, as well as due to a greater adherence to the use of pressure reducing devices $^{(11)}$. On the other hand, the set of resources for pressure relief, monitoring the degree of risk, incidence and prevalence, as well as raising awareness of the teams have been important in the Brazilian context ${ }^{(14)}$.

Development of clinical guidelines has become essential for the health system to ensure the use of the best evidence, considering available resources, as well as the acquisition of new technologies and training of professionals. Currently, access to scientific information is facilitated by the media, which makes it possible to elaborate a pressure ulcer protocol with greater rigor in the selection of the different recommendations available.

Elaboration and implementation of protocols should take into account the quality of recommendations available and feasibility of implementation, besides the engagement of professionals involved in the work process and the nurse's professional autonomy ${ }^{(16)}$.

A total of 21 protocols for pressure ulcer prevention were analyzed according to the German national standard, which indicated that two important aspects, such as training and permanent education, were absent in almost all protocols. Therefore, there is a need for greater investment in the elaboration of protocols, considering these aspects ${ }^{(17)}$.

The standardization of protocols with the elements discussed in this study could systematize nursing care and direct the actions of professionals involved in the care process.

Wound care is part of the nurses' attributions according to the increase of new knowledge regarding the different types of lesions, tissue healing process, as well as the scientific and technological development of nursing assistance to these clients, and especially to those with risk for developing it ${ }^{(30)}$.

Nursing has sought to remedy such difficulties and this has led professionals to improve their practices through specializations. Providing care for people with skin lesions requires specific knowledge and clinical experience to establish preventive and treatment interventions.

Nurses should take responsibility for their role in the prevention and treatment of pressure ulcers by seeking knowledge, skills and competences for the development of systematization of nursing care.

Thus, a situational diagnosis becomes fundamental in the development of protocols since the importance of evaluation in relation to the skin care was verified. Some parameters used to identify fundamental aspects in the evaluation of care provided ${ }^{(28)}$ were daily evaluation of the skin (94.0\%); use of pressure reducers (7.5\%); risk recording (22.6\%); repositioning every two hours, at least (66.2\%); consultation with nutrition (34.3\%); stage I pressure ulcer (20.2\%); and stage II pressure ulcer (30.9\%).

In order to implement actions and ensure the implementation of protocols, one of the strategies is permanent education because it increases the competence of professionals, and these can be multipliers to enable the achievement of results with prevention protocols ${ }^{(21-22,25-29)}$. Actions that are divergent from 
Evidence-Based Practice are detrimental to the integrity of patients' skin ${ }^{(23-24)}$.

Protocols are permanent education tools and, although establishing guidelines for adopting the best behavior, they preserve the health professional's autonomy ${ }^{(9,11,13)}$. Permanent education should be carried out in a continuous way, aiming at the transformation of health problems and providing changes in the work process, with the inclusion of clients, families and health professionals, in a participatory and effective way.

Building a protocol must be linked to the demand of the patient and the specificity of the treatment performed by the patient. The involvement of professionals in the elaboration of the protocol increases adherence and the chances of success in the implementation thereof.

\section{Conclusion}

This integrative review showed that protocols for the prevention of pressure ulcer should be elaborated with the following structure: situational diagnosis; characterization of clients; definition of therapeutic options; creation of service standards; and implementation of the protocol.

In this way, aspects directly related to the evaluation of risk for developing pressure ulcer, besides the fundamental aspects for the implementation of the protocol, should be contemplated in the elaboration thereof, that is, risk assessment, results achieved, systematization of care, situational diagnosis and permanent education are the constituent elements of the pressure ulcer prevention protocol.

\section{Collaborations}

Stuque AG, Sasaki VDM, Teles AAS and Sonobe HM contributed to the study design, analysis and writing. Santana ME and Rabeh SAN contributed to the analysis and writing of the article. All the authors contributed in the critical review of the content and approval of the final version to be published.

\section{References}

1. Brem H, Maggi J, Nierman D, Rolnitzky L, Bell D, Rennert R, et al. High cost of stage IV pressure ulcers. Am J Surg. [Internet]. 2010 Oct [cited 2016 nov. 12]; 200(4):473-7. Available from: http:// doi.org/10.1016/j.amjsurg.2009.12.021

2. Pereira AGS, Santos CT, Menegon DB, Mello BS, Azambuja F, Lucena AF. Mapping the nursing care with the NIC for patients in risk for pressure ulcer. Rev Esc Enferm USP. [Internet]. 2014 [cited 2016 Nov. 12]; 48(3):454-61. Available from: http:// www.scielo.br/scielo.php?script $=$ sci_arttext\&pid=S0080-62342014000300454\&lng=en\&n$\mathrm{rm}=\mathrm{iso}$

3. Silva AJ, Pereira SM, Rodrigues A, Rocha AP, Varela J, Gomes LM et al. Economic cost of treating pressure ulcers: a theoretical approach. Rev Esc Enferm USP. [Internet]. 2013 [cited 2016 Nov. 12]; 47(4):971-6. Available from: http://www.scielo. br/scielo.php?script=sci_arttext $\&$ pid=S008062342013000400971\&lng=en\&nrm=iso

4. Urbanetto JS, Santos MACN, Poltozi, AF, Pechansky ALC, Hax G, Custódio A. Relação entre a dependência de cuidados, risco e úlcera por pressão. Enferm Foco. [Internet]. 2012 [citado 2016 nov. 12]; 3(2):198-201. Disponível em: http://revista.portalcofen.gov.br/index.php/ enfermagem/article/view/384

5. Correia JN, Bonette A. Evaluation of risk in the development of pressure-caused tissue lesion in ICU patients. Rev Saúde Pesq [Internet]. 2011 [cited 2016 Nov. 12]; 4(1): 123-7. Available from: http://periodicos.unicesumar.edu.br/index.php/ saudpesq/ article/viewFile/1597/1212

6. Soares CB, Hoga LAK, Peduzzi M, Sangaleti C, Yonekura T, Silva DRAD. Integrative review: concepts and methods used in nursing. Rev Esc Enferm USP [Internet]. 2014 [cited 2016 Nov. 12]; 48(2):335-45. Available from: http://www.scielo. br/scielo.php?script=sci_arttext $\&$ pid=S008062342014000200335\&lng=en

7. Caldana G, Gabriel CS, Bernardes A, Évora YDM. Indicadores de desempenho em serviço de enfermagem hospitalar: revisão integrativa. Rev Rene [Internet] 2011. [cited 2016 Nov. 12]; 12(1):189-97. Available from: http://www.revistarene.ufc.br/ revista/index.php/revista/article/view/146/57 
8. Stillwell SB, Fineout-Overholt E, Melnyk BM, Williamson KM. Searching for the Evidence. Am J Nurs [Internet] 2010. [cited 2016 Nov. 12]; 110(5):41-7. Available from: http://journals.lww. com/ajnonline/Fulltext/2010/05000/Evidence_ Based_Practice,_Step_by_Step_Searching.24.aspx

9. Rogenski NMB, Kurcgant P. The incidence of pressure ulcers after the implementation of a prevention protocol. Revista Latino-Am Enfermagem. [Internet]. 2012 [cited 2016 Nov. 12]; 20(2):333-9. Available from: http://www. redalyc.org/articulo.oa?id=281422733016

10. Silva RA, Borges EL, Donoso MTV. Risco para desenvolvimento e prevalência de úlcera por pressão de uma unidade de internação de um hospital universitário. Nursing. 2011; 13(156):24852.

11. Vandenkerkhof EG, Friedberg E, Harrison MB. Prevalence and risk of pressure ulcers in acute care following implementation of practice guidelines: annual pressure ulcer prevalence census 1994-2008. J Healthc Qual [Internet]. 2011 [cited 2016 Nov. 12]; 33(5):58-67.Available from: http://onlinelibrary.wiley.com/doi/10.1111/ j.1945-1474.2011.00127.x/abstract;jsessionid=23476FA1862BDF599BFAB251D547E023.f04t04

12. Rocha AF, Guariente MHDM, Barros SKSA, Morooka M, Mouro DL. Pressure ulcers: incidence and associated risk factors in patients of a university hospital. Rev Enferm UFPE on line [Internet]. 2010 [cited 2016 Nov. 12]; 4(3):150614. Available from: http://www.revista.ufpe.br/ revistaenfermagem/index.php/revista/article/ viewArticle/1148

13. Silva EWNL, Araújo RA, Oliveira EC, Falcão VTFL. Applicability of the prevention protocol of pressure ulcers in Intensive Care Unit. Rev Bras Ter Intensiva [Internet]. 2010 [cited 2016 Nov. 12]; 22(2):175-85. Available from: http://www.scielo.br/scielo.php?pid=S0103507X2010000200012\&script=sci_arttext

14. Louro M, Ferreira M, Póvoa P. Evaluation of a prevention protocol of pressure ulcers. Rev Bras Ter Intensiva [Internet]. 2007 [cited 2016 Nov. 12]; 19(3):337-41. Available from: http://www.scielo. br/scielo.php?script=sci_arttext\&pid=S0103507X2007000300012\&lng=en\&nrm=iso
15. Menegon DB, Bercini RR, Brambila MI, Scola ML, Jansen MM, Tanaka RY. Implementation of a care protocol for prevention and treatment of pressure ulcers at Hospital de Clínicas de Porto Alegre, Brazil. Rev HCPA [Internet]. 2007 [cited 2016 Nov. 12]; 27(2):61-4. Available from: http://www.seer. ufrgs.br/hcpa/article/viewFile/2031/1174

16. Wimpenny P, Van Zelm R. Appraising and comparing pressure ulcer guidelines. Worldviews Evid Based Nurs [Internet]. 2007 [cited 2016 Nov. 12]; 4(1):40-50. Available from: http://www.ncbi. nlm.nih.gov/pubmed/17355409

17. Wilborn D, Halfens R, Dassen T. Pressure Ulcer: prevention protocols and prevalence. J Eval Clin Pract [Internet]. 2006 [cited 2016 Nov. 12]; 12(6):630-8. Available from: http://pesquisa. bvsalud.org/portal/resource/pt/mdl-17100862

18. Stephen-Haynes J. National Institute for Health and Chnical Excellence - NICE pressure ulcer guideline: summary and implications for practice. Br J Comm Nurs [Internet]. 2006 [cited 2016 Nov. 12]; 11(6):20-4. Available from: http://www.ncbi. nlm.nih.gov/pubmed/16835566

19. Barbut F, Parzybut B, Boelle PY, Neyme D, Farid R, Kosmann MJ.Pressuresoresin auniversity hospital. Presse Med [Internet]. 2006 [cited 2016 Nov. 12]; 35(5):769-78. Available from: http://www.ncbi. nlm.nih.gov/pubmed/?term=16710144

20. Barros SKSA, Anami EHT, Moraes MP. A elaboração de um protocolo para prevenção de úlcera de pressão por enfermeiros de um hospital de ensino. Nursing. 2003; 6(63):29-32.

21. Revello K, Fields W. A performance improvement project to increase nursing compliance with skin assessments in a rehabilitation unit. Rehabil Nurs [Internet]. 2012 [cited 2016 Nov. 12]; 37(1):3742. Available from: http://www.ncbi.nlm.nih.gov/ pubmed/22271220

22. Asimus M, MacLellan L, Li P. Pressure ulcer prevention in Australia: the role of the nurse practitioner in changing practice and saving lives. Int Wound [Internet]. 2011 [cited 2016 Nov. 12]; 8(5):508-13. Available from: http://onlinelibrary.wiley.com/doi/10.1111/ j.1742-481X.2011.00824.x/essionid= A3B7B700053E246704E988113147285B.f01t03 
23. Dahlstrom M, Best T, Baker C, Doeing D, Davis A, Doty J, Arora VM. Improving identification and documentation of pressure ulcers at an urban academic hospital. Jt Comm J Qual Patient Saf. [Internet]. 2011 [cited 2016 nov. 12]; 37(3):12330. Available from: http://www.ncbi.nlm.nih.gov/ pmc/articles/ PMC3278963/?tool=pubmed

24. Passos SSS, Sadiguski D, Carvalho ESS. Promotion of skin integrity of patients with dependence on mobility: a team of speech of nursing. Rev Enferm UFPE on line [Internet]. 2010 [cited 2016 Nov. 12]; 4(3):1498-1505. Available from: http:// www.revista.ufpe.br/revistaenfermagem/index. php/revista/article/view/1091

25. Valença MP, Lima PO, Pereira MM, Santos RB. Nurses' perception on the prevention of pressure ulcers at a school hospital in Recife city. Rev Enferm UFPE on line [Internet]. 2010 [cited 2016 Nov. 12]; 4(2):673-82. Available from: http:// www.revista.ufpe.br/revistaenfermagem/index. php/revista/article/view/852

26. De Laat EH, Schoonhoven L, Pickkers P, Verbeek AL, Achterberg TV. Implementation of a new policy results in a decrease of pressure ulcer frequency. Int J Qual Health Care. [Internet]. 2006 [cited 2016 Nov. 12]; 18(2):107-12. Available from: http:// intqhc.oxfordjournals.org/content/18/2/107. long
27. Clarke HF, Bradley C, Whytock S, Handfield S, Van der Wal R, Gundry S. Pressure ulcers: implementation of evidence-based nursing practice. J Adv Nurs [Internet]. 2005 [cited 2016 Nov. 12]; 49(6):578-90. Available from: http:// onlinelibrary.wiley.com/doi/10.1111/j.13652648.2004.03333.x/abstract

28. Lyder CH, Preston J, Grady JN, Scinto J, Allman R, Bergstrom N, Rodeheaver G. Quality of care for hospitalized medicare patients at risk for pressure ulcers. Arch Intern Med [Internet]. 2001 [cited 2016 Nov. 12]; 161(12):1549-54. Available from: http://archinte.jamanetwork.com/article. aspx?articleid $=648432$

29. Xakellis GC, Frantz RA, Lewis A, Harvey P. Translating pressure ulcer guidelines into practice: it's harder than it sounds. Adv Skin Wound Care. [Internet]. 2001 [cited 2016 nov. 12]; 14(5):249-56. Available from: http://ovidsp. tx.ovid.com/sp-3.15.1b/ovidweb.cgi

30. Domanski RC, Borges EL. Manual para prevenção de lesões de pele: recomendações baseadas em evidências. Rio de Janeiro: Rubio; 2012. 